\title{
Methods for the recovery of nutrients and energy from swine manure. 2. Protein
}

\author{
L. Boersma ${ }^{1}$, E. Gasper ${ }^{1}$, J. E. Oldfield ${ }^{2}$ and P. R. Cheeke ${ }^{2}$ \\ ${ }^{1}$ Department of Soil Science, Oregon State University, Corvallis, Oregon, USA \\ 2 Department of Animal Science, Oregon State University, Corvallis, Oregon, USA
}

Accepted: 5 June 1978

Key words: Swine manure, protein, algae, methane, bacteria, nutrient recovery, energy recovery, fermenter, digester, biogas

\section{Summary}

Tables 1 and 2 show combustible energy content of products involved in raising pigs from 50 to $100 \mathrm{~kg}$. Values shown are for a one-year period with pigs being fed during 350 days. Protein consumption by the pigs and protein recovery from waste products are also shown.

The tabulations shown here in combination with those of Part 1 indicate that the yield of biogas is reduced by inclusion of the fermenter. However, substantial quantities of protein can be produced. The relative advantages can not be judged without a comparison of costs and benefits. These comparisons have not been made. Conclusions depend on the relative costs of energy and protein.

Because difficulties are involved with algae production, not the least of which is the cost of production facilities, we favor the management scheme where straw is used in fermenter as well as digester, and growth of algae is not attempted.

\section{Methane and yeast or microfungi}

\section{Introduction}

In Part 1 of this series (Boersma et al., 1981), we reported on the use of manure to produce biogas. The discussion included descriptions of the composition of the feed and the manure. Energy balances and materials balances were presented. Here we report a management system which emphasizes the recovery of protein by growing yeast, microfungi, or algae in the liquid phase of the manure (Fig. 1). Reference will be made to information presented in Part 1 (Boersma et al., 1981).

Organic matter dissolved in the liquid phase of the fresh manure may be used as a substrate for the growth of yeast or microfungi. These organisms convert the orga- 
Table 1. Energy values of several products used and produced on a farm where pigs are raised from 50 to $100 \mathrm{~kg}$. There are $100 \mathrm{pigs}$ at all times. The through-put is $560 \mathrm{pigs} / \mathrm{year}$.

\begin{tabular}{lr}
\hline Products & Energy content $\left(10^{9} \mathrm{~J} / \mathrm{yr}\right)$ \\
No straw & \\
pork $(19600 \mathrm{~kg} / \mathrm{yr})$ & 247 \\
yeast $(2135 \mathrm{~kg} / \mathrm{yr})$ & 42 \\
algae $(5906 \mathrm{~kg} / \mathrm{yr})$ & 147 \\
biogas $\left(5005 \mathrm{~m}^{3} / \mathrm{yr}\right)$ & 113 \\
nitrogen $(787 \mathrm{~kg} / \mathrm{yr})$ & 59 \\
& \\
With straw & \\
pork $(19600 \mathrm{~kg} / \mathrm{yr})$ & 247 \\
yeast $(10430 \mathrm{~kg} / \mathrm{yr})$ & 209 \\
algae $(2187 \mathrm{~kg} / \mathrm{yr})$ & 54 \\
biogas $(10640 \mathrm{~m} / \mathrm{yr})$ & 239 \\
nitrogen $(560 \mathrm{~kg} / \mathrm{yr})$ & 42 \\
\hline
\end{tabular}

nic matter into cell mass. Harvesting of the cell mass leaves an effluent which still contains nutrients and minerals for the growth of algae. The effluent also may be used on land for its fertilizer value. The harvested biomass can be fed to the pigs as a protein supplement in their diet.

\section{Process description}

For this discussion we assume that a gutter flushing system is used to remove the manure from the animal quarters. Flushing at the rate of $140 \mathrm{l} / \mathrm{h}$ dilutes the $300 \mathrm{l}$ of manure to a volume of $3660 \mathrm{l} /$ day (Fig. 1). Other rates of flushing may be chosen according to local needs. The diluted manure is collected in a sedimentation pit where the solids are separated from the liquids by settling. The solids are pumped into an anaerobic digester. The liquids overflow into a holding tank from which they are pumped to a fermentation vessel. The holding tank provides temporary storage so that flow to the fermenter can be regulated and allows additional sedimentation to occur. The liquid remaining after harvesting the yeast cells still contains most of the dissolved minerals in the manure. This effluent can be used as a fertilizer or as a substrate for the growth of algae. The effluent from the digester may be added to that from the fermenter and used in the same manner.

\section{Fermenter}

A conceptual model of the culture of yeast in the liquid phase of swine manure may be based on recent developments in fermentation technology and the culture of single cell organisms (Forss et al., 1974; Humphrey, 1974; Meyrath, 1975).

It is assumed that $3000 \mathrm{l}$ of diluted manure are supplied to the fermenter each day in a continuous flow (Fig. 1). Conventional processes of yeast manufacture require a retention time of 3 to $5 \mathrm{~h}$. At a retention time of $5 \mathrm{~h}$, the volume of the fermenter must be $6251(3000 \mathrm{l} / \mathrm{h} \times 5 / 24)$. To allow for the expansion of the substrate due to gassing and foaming, the volume of the fermenter should be increased to about 
Table 2. Energy inputs and outputs for the system of management shown in Fig. 1. The numbers shown pertain to a period of one year.

\begin{tabular}{|c|c|c|c|c|c|c|c|}
\hline \multirow[t]{2}{*}{ Category } & & \multicolumn{3}{|c|}{ No straw } & \multicolumn{3}{|c|}{ With straw } \\
\hline & & $\begin{array}{l}\text { energy } \\
\left(10^{9} \mathrm{~J}\right)\end{array}$ & $\begin{array}{l}\text { energy } \\
(\% 0 \text { of } \\
\text { total } \\
\text { input) }\end{array}$ & $\begin{array}{l}\text { protein } \\
(\mathrm{kg})\end{array}$ & $\begin{array}{l}\text { energy } \\
\left(10^{9} \mathrm{~J}\right)\end{array}$ & $\begin{array}{l}\text { energy } \\
\text { ( } \% \text { of } \\
\text { total } \\
\text { input) }\end{array}$ & $\begin{array}{l}\text { protein } \\
(\mathrm{kg})\end{array}$ \\
\hline \multicolumn{8}{|l|}{ Energy input } \\
\hline corn grain & & 1871 & 71.5 & 9950 & 1871 & 42.9 & 9950 \\
\hline soybeans & & 134 & 6.1 & 3185 & 134 & 3.7 & 3185 \\
\hline straw for digester & & - & & & 528 & 12.1 & \\
\hline straw for fermenter & & - & & & 1214 & 27.9 & \\
\hline \multicolumn{8}{|l|}{ farming } \\
\hline - fuel \& electricity & 227 & & & & & & \\
\hline- fertilizer & 136 & & & & & & \\
\hline - labor \& machinery & 91 & & & & & & \\
\hline - livestock maintenance & 100 & & & & & & \\
\hline \multirow[t]{3}{*}{ - feed processing } & 33 & & & & & & \\
\hline & 587 & 587 & 22.4 & & 587 & 13.4 & \\
\hline & & 893 & 100.0 & 12775 & 4334 & 100.0 & 12775 \\
\hline \multicolumn{8}{|c|}{ Energy output, useful products } \\
\hline pork & & 247 & 9.4 & & 247 & 5.7 & \\
\hline yeast & & 42 & 1.6 & 1085 & 209 & 4.8 & 5439 \\
\hline algae & & 147 & 5.6 & 2835 & 54 & 1.2 & 1132 \\
\hline biogas & & 113 & 4.3 & & 247 & 5.5 & \\
\hline \multirow[t]{2}{*}{$\mathrm{N}$} & & 59 & 2.2 & & 42 & 1.0 & \\
\hline & & 608 & 23.2 & 3920 & 799 & 18.3 & 6571 \\
\hline \multicolumn{8}{|l|}{ Other energy sinks } \\
\hline heat loss from pigs & & 1089 & 41.6 & & 1089 & 25.0 & \\
\hline $\mathrm{CO}_{2}$ and other gases & & 544 & 20.8 & & 1717 & 39.4 & \\
\hline \multirow[t]{2}{*}{ other (e.g. fiber residue) } & & 377 & 14.4 & & 754 & 17.2 & \\
\hline & & 2010 & 76.8 & & 3560 & 81.7 & \\
\hline
\end{tabular}

2000 1. The substrate has a COD of $16 \mathrm{~kg} /$ day and contains $2.4 \mathrm{~kg} \mathrm{~N} / \mathrm{day}$. We shall assume that only $\mathrm{N}$ in the ammonium form is readily assimilated by the yeast or microfungi.

If all of the COD is attributed to organic carbon that can be assimilated by the organisms, then a theoretical yield of $0.38 \mathrm{~g}$ of cells/g of COD is possible (Sykes, 1975). The expected yield is therefore $6.1 \mathrm{~kg}$ cell matter/day $(16 \mathrm{~kg} \mathrm{COD} /$ day $\times$ $0.38 \mathrm{~kg}$ biomass $/ \mathrm{kg}$ COD). In general, the $\mathrm{N}$ content of the yeast ranges from 8 to $10 \%$ of the dry matter so that about $0.5 \mathrm{~kg} \mathrm{~N} /$ day are removed, corresponding to a yield of $3.1 \mathrm{~kg}$ of crude protein per day $(\mathrm{N} \times 6.25)$, which is equivalent to $34 \%$ of the amount of protein supplied by soybeans and $8.5 \%$ of the total protein requirement. 


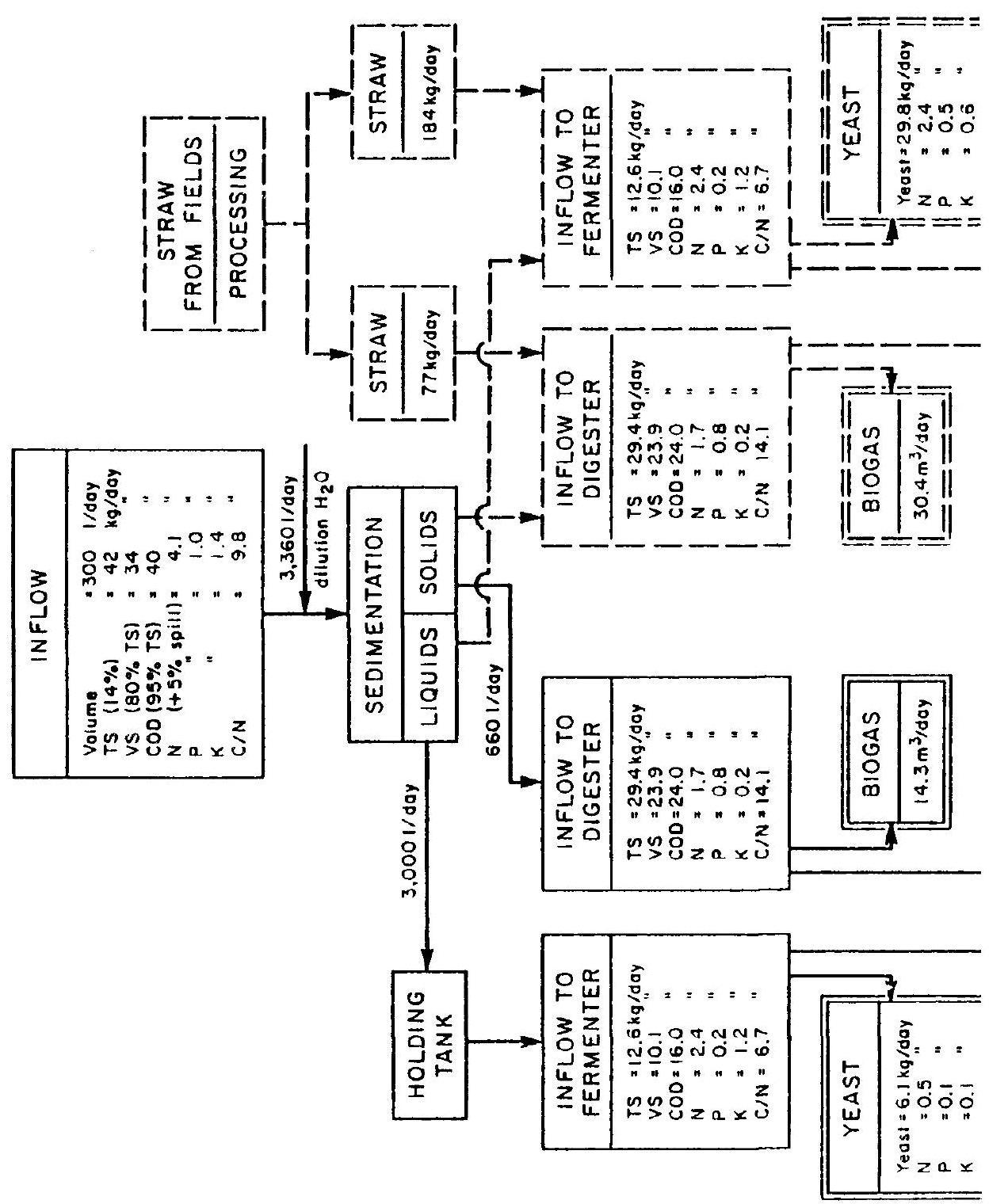


RECOVERY OF NUTRIENTS AND ENERGY FROM SWINE MANURE. 2
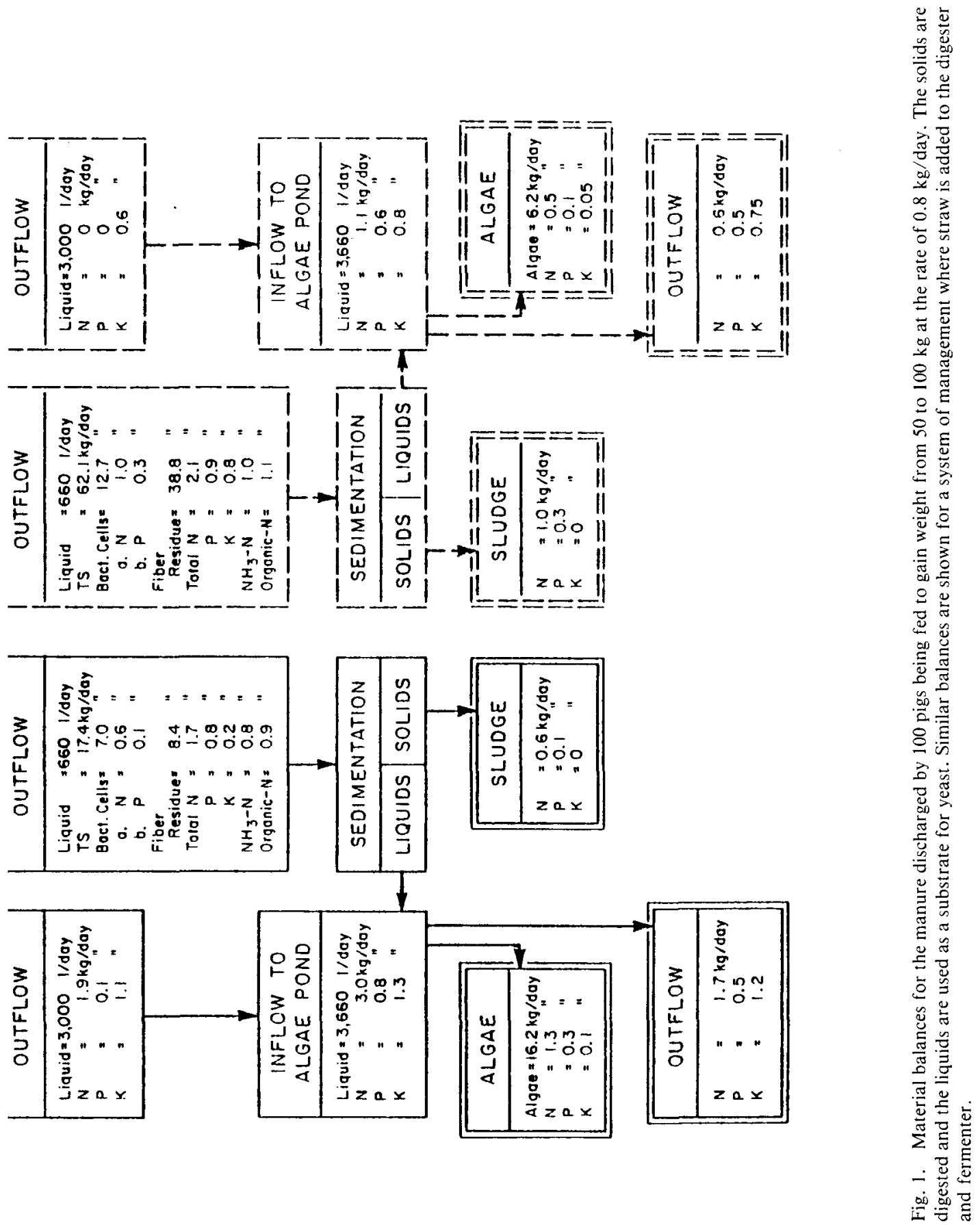


\section{Addition of carbon source}

The unused ammonium $\mathrm{N}$, namely $2.4-0.5=1.9 \mathrm{~kg} /$ day, can also be converted into yeast or fungal protein by the addition of organic carbon. Such a procedure has advantages over supplying the excess $\mathrm{N}$ to outdoor ponds for algal growth. The growth of yeast and fungi does not depend on solar radiation and growth rates are much faster than for algae. The culture of yeast and fungi requires less space than the culture of algae in outdoor ponds. Also, better control over the quality of the product can be exercised.

Assuming that yeast cells contain $8 \% \mathrm{~N}$ by weight, the excess $\mathrm{N}$ of $1.9 \mathrm{~kg} /$ day could be converted to $23.75 \mathrm{~kg}$ of yeast $(1.9 \mathrm{~kg} \mathrm{~N} / 0.08)$. Additional COD is required to accomplish this. This can be supplied by properly pretreated cellulosic wastes such as straw. Using the yield of $0.38 \mathrm{~kg}$ of cells $/ \mathrm{kg} \mathrm{COD}$, the requirement is $23.7 / 0.38=62.5 \mathrm{~kg}$ COD. This could be supplied by $58.6 \mathrm{~kg}$ of sugars $(62.5 \mathrm{~kg}$ $\mathrm{COD} / 1.067 \mathrm{~kg} \mathrm{O}$ per $\mathrm{kg}$ sugar $=58.6 \mathrm{~kg}$ sugar).

The sugars may be obtained by the hydrolysis of straw. Assume that the straw containts $64 \%(\mathrm{w} / \mathrm{w})$ cellulose and hemicellulose and that $50 \%$ is converted to sugars. Then $1 \mathrm{~kg}$ of straw yields $1.0 \times 0.64 \times 0.50=0.32 \mathrm{~kg}$ of sugar. The amount of straw to be hydrolyzed is therefore $184 \mathrm{~kg} /$ day. The fermenter receives $16+62.5$ $=78.5 \mathrm{~kg}$ of COD and the yield of yeast cells is $29.8 \mathrm{~kg}$ /day with a protein content of $50 \%$ by weight $(78.5 \mathrm{~kg}$ COD $\times 0.38 \mathrm{~kg}$ cells per $\mathrm{kg}$ COD). The protein yield of $14.9 \mathrm{~kg} /$ day is $164 \%$ of that supplied by soybeans and $41 \%$ of the total requirement for protein.

After removing the yeast cells, the effluent contains no solids, some $\mathrm{N}$ and $\mathrm{P}$, and about $1.0 \mathrm{~kg} \mathrm{~K} /$ day. The actual amount of minerals in the effluent depends on the chemical composition of the yeast or microfungi. The efficient use of assimilable sugars and nitrogen depends on the rate at which oxygen can be supplied to the growing cells. Technical limitations to efficient oxygen transfer to the yeast or microfungi have not been overcome.

The feasibility of converting all of the nitrogen in the liquid phase of the manure to protein depends on finding solutions to technical problems including the hydrolysis of the straw and fermentation and on finding reliable sources for a continued supply of suitable waste products.

\section{Back-feeding}

The proposed scheme for the recovery of yeast or microfungal protein from swine waste involves returning some of the harvested biomass slurry, with a high concentration of cells, to the main fermentation vessel. The added cells increase the rate at which the substrate can be broken down. As a consequence, the rate at which raw material is added can be increased. Back-feeding increases the yield per unit of fermenter volume for a substrate low in organic matter.

The possibility of decreasing the retention time through back-feeding means that the size of the fermentation vessel can be reduced. In order to treat the $3000 \mathrm{l}$ of waste water per day at the conventional retention time of $5 \mathrm{~h}$, one-fifth of the $625 \mathrm{l}$ of culture volume inside the fermentation vessel must be replaced every hour. This corresponds to a dilution rate of $0.2 / \mathrm{h}$. A dilution rate of $1.0 / \mathrm{h}$, made possible 
through back-feeding, means that the culture volume can be reduced from 6251 to 125 l. The total volume of the fermentation vessel, allowing for expansion by gassing and foaming, would then be 4001 instead of 20001.

\section{Selection of organism}

Selection of either yeasts or microfungi depends on several considerations. Among these are the possible need for sterilization of the waste water to favor growth of the organism of choice, the need to minimize cooling costs, and problems of harvesting. The need for sterilization might be eliminated by using an organism which can tolerate hydrogen ion concentrations in the range of $\mathrm{pH} 3$ to 4.5. Bacterial growth is greatly reduced or eliminated at this acidity.

Harvesting can be done by centrifugation, aggregation, or flocculation. Of these, centrifugation is the most expensive method. The preferred organism should have a strong tendency to aggregate or flocculate to facilitate harvesting by gravitational sedimentation or by filtration. Furthermore, the organism should be able to tolerate elevated temperatures of 40 to $45^{\circ} \mathrm{C}$ in order to reduce cooling costs. Yeast strains with these desired properties have been isolated (Meyrath, 1975). Some are available from the American Type Culture Collection, such as Candida acidothermophilum (ATCC No 20381).

We propose use of the microfunges Paecilomyces varioti. This organism is being used successfully in Finland for the production of the so called 'PEKILO' protein from sulfite liquor at pulp mills (Forss et al., 1974). A 10000 tonnes/year plant has been built by United Paper Mills, Ltd., at Jämsänkoski in central Finland and has been in operation since 1974. The 'PEKILO' protein is sold as an ingredient in animal feedstuff for calves, pigs, and poultry.

$P$. varioti has several dinstinct advantages over the Candida or Torula yeast conventionally grown on sulfite liquor. Its crude protein content is in the range of 55 to $60 \%$, whereas that of the Candida yeast is from 45 to $50 \%$. By virtue of its mycelial structure, the microfungus can be harvested by drum filtration while the small cell size of the Candida yeast requires centrifugal separation, which is much more expensive and energy intensive. The use of strains of yeast with the strong ability to flocculate (Meyrath, 1975) could negate this advantage of the microfungus by allowing the harvesting of yeast by gravity settling. The microfungus has the further advantage that its fibrous nature allows the removal of large amounts of water by mechanical pressing to a solids content of 30 to $40 \%$. This feature is of economic importance because mechanical dewatering is much cheaper than drying entirely by heat as is necessary for the yeast.

\section{Cooling requirements}

The growth of yeast releases about $16.7 \mathrm{MJ} / \mathrm{kg}$ of dry matter. The indicated yield of $29.8 \mathrm{~kg} /$ day generates $500 \mathrm{MJ}$ which can raise the temperature of 30001 of diluted waste by $39.7^{\circ} \mathrm{C}$. Some of this heat is needed to raise the temperature of the inflow to the fermentation vessel. The temperature of the liquid waste in the holding tank depends on the local climate. At our location, the temperature of the waste water 
was as low as $5{ }^{\circ} \mathrm{C}$ in the winter and as high as $25^{\circ} \mathrm{C}$ in the summer (Boersma et al., 1978). To raise the temperature of the inflow from $5{ }^{\circ} \mathrm{C}$ to $45^{\circ} \mathrm{C}$ would require $500 \mathrm{MJ} /$ day. Thus, cooling would be minimal during the winter months. At $25^{\circ} \mathrm{C}$, only $250 \mathrm{MJ} /$ day would be required for heating the inflow. Cooling would therefore be necessary during the summer. Consideration should be given to the possibility of heating the inflow to the digester so that this heating requirement is eliminated.

\section{Anaerobic digester}

Management of the anaerobic digester was discussed in detail in Part 1 (Boersma et al., 1981). Yields are lower here because part of the COD is transferred to the fermenter. Yields of $14.3 \mathrm{~m}^{3}$ biogas/day without the addition of cellulosic waste and $30.4 \mathrm{~m}^{3} /$ day with the addition of cellulosic waste are indicated. We have not discussed uses for the gas here, but suggest that a useful application would be the processing of the single cell protein.

\section{Use of effluents}

Effluent streams from the digester and from the fermenter are available for further use. They can be used separately or in combination. We assume the mixing of the two out flow streams. When spread on land, the $3660 \mathrm{l} /$ day provide a depth of water of $0.0366 \mathrm{~cm}$ per ha per day. Spreading the outflow from 10 days on 1 ha provides $0.37 \mathrm{~cm}$ of water and $30 \mathrm{~kg} \mathrm{~N}, 8 \mathrm{~kg} \mathrm{P}$, and $13 \mathrm{~kg} \mathrm{~K}$. If all the water were supplied to the 15.26 ha needed to raise the grain, they would receive $0.84 \mathrm{~cm}$ of water per year and $68.8 \mathrm{~kg} \mathrm{~N}, 18 \mathrm{~kg} \mathrm{P}$ and $29.8 \mathrm{~kg} \mathrm{~K}$.

Distribution of water can only be done during the growing season. The storage requirement for 200 days would be $732 \mathrm{~m}^{3}$, equivalent to a reservoir $3 \mathrm{~m}$ deep with a floor area measuring $12.2 \times 20 \mathrm{~m}$.

\section{Algae}

\section{Introduction}

Dissolved nutrients in the liquid phase of the manure can also be recovered by photoautotrophic organisms such as algae. The manure stream can be managed in two different ways in order to accomplish this. The effluents from the digester and/or the fermenter can be used as a substrate for algae or the fresh manure may be separated into solid and liquid fractions to be used separately for anaerobic digestion and as a substrate for algae, respectively. The second method omits the use of the liquid phase for the growth of yeast in the fermenter but makes it available for algal growth.

\section{Recovery of nutrients by photoautotrophs}

High levels of radiant energy and temperatures in the range of 25 to $35^{\circ} \mathrm{C}$ are desirable for maximum rates of growth of algae. Radiation intensity decreases rapidly with culture depth, even in clear solutions. The liquid phase of swine manure is far from clear. It contains color compounds in addition to suspended solids. Further- 
more, the presence of dissolved organic matter supports the rapid growth of bacteria indigenous to the waste. All of these limitations to light penetration can in part be overcome by dilution with large volumes of water.

The surface area required for the daily volume of diluted waste is determined by the depth of the culture, the retention time, and the total volume. The depth is determined by the radiation intensity. At high levels of radiation the depth can be greater than at low levels. The retention time is determined by the rate at which algae grow and therefore depends on day length, radiation intensity, and temperature. The cultures can be deeper and the retention times shorter during the summer than during the winter. For a daily inflow of $3660 \mathrm{l}$, a depth of $15 \mathrm{~cm}$, and a retention time of 4 days the surface area would be $97.6 \mathrm{~m}^{2}$. For a depth of $10 \mathrm{~cm}$ and a retention time of 8 days, the surface area would be $8 \times 3660 \times 0.001 / 0.10=292.8 \mathrm{~m}^{2}$.

It may be advisable to limit the culture of algae to the summer in geographic regions with a short day length and low levels of solar radiation during the winter. The substrate could be stored for later use. A decision on whether or not to do so must be based on a comparison of the cost of storage with the cost of building and operating the larger pond.

We consider two methods of management, namely one where the effluent from the digester is used and one where the liquid phase of the manure is used.

\section{Use of digester effluent - fermenter not used}

The entire flow of fresh manure is routed to the anaerobic digester. The effluent from the digester is clarified in a storage tank by allowing settling to occur. The clarified liquid is used as a substrate for algae. The rate of outflow from the digester and the concentration of nutrients in it was described in Part 1. The effluent does not need further dilution, because soluble organic compounds have been removed. Adequate growth of algae is expected at a culture depth of $15 \mathrm{~cm}$ and a retention time of 8 days. The required surface area would be $48 \mathrm{~m}^{2}$ for a daily volume of $900 \mathrm{l}$. This volume results when $600 \mathrm{l} /$ day of dilution water are used instead of the $300 \mathrm{l} /$ day indicated in Fig. 1 of Part I.

The digester effluent contains $4.1 \mathrm{~kg}$ total $\mathrm{N}, 50 \%$ of which is present in the form of $\mathrm{NH}_{3}-\mathrm{N}$ and readily assimilated by algae. We measured assimilation of 30 to $50 \%$ of the $\mathrm{N}$ by algae under field conditions (Boersma et al., 1978). This percentage can be increased by proper management. The effluent is expected to yield $(4.1 \times 0.50)$ $\times 0.50 \times 6.25=6.2 \mathrm{~kg}$ protein per day when no straw is added to the digester. With straw added, the outflow contains $5.2 \mathrm{~kg} \mathrm{~N} /$ day and the expected yield is $8.1 \mathrm{~kg}$ protein per day. Assuming a protein content of $50 \%$, the corresponding yields of algal dry matter are 12.5 and $16.2 \mathrm{~kg} /$ day. The yields may be greater than indicated, if the organic- $\mathrm{N}$ present in the digester effluent is converted to $\mathrm{NH}_{3}-\mathrm{N}$ by bacterial ammonification.

The protein yields correspond to $68 \%$ and $89 \%$ of the protein supplied by the soybeans and to $17 \%$ and $22 \%$ of the total protein requirement. These comparisons must be revised downward by allowing for the poor digestibility of the algal cells. 


\section{Use of fermenter and digester effluents}

With the fermenter included in the management system, the combined outflows from fermenter and digester contain 3.0 and $1.1 \mathrm{~kg} \mathrm{~N} /$ day with and without the addition of straw, respectively. The yields of algal protein, assuming all the $\mathrm{N}$ to be in a form which is readily assimilated, and a utilization rate of $43 \%$, are $(3.0 \times 0.43)$ $\times 0.50 \times 6.25=8.1$ and $1.1 \times 0.50 \times 6.25=3.1 \mathrm{~kg} /$ day. The total yields of protein from fermenter and digester are $3.1+8.1=11.2$ and $14.9+3.1=18.0$ $\mathrm{kg} /$ day corresponding to $123.1 \%$ and $197.8 \%$ of the protein supplied by the soybeans or $30.7 \%$ and $49.3 \%$ of the total requirement for protein.

\section{Use of the liquid phase}

When the liquid phase of fresh manure is used as a substrate for algal growth it becomes important to suppress the growth of bacteria. These grow readily due to the high concentration of dissolved organic matter. Adequate penetration of light and suppression of bacterial growth is achieved by dilution. We found that a 50 -fold dilution of the $300 \mathrm{l}$ of liquid manure discharged by the pigs assured stable cultures of algae. Because of the need for large volumes of water, flushing is the most logical means for manure transport.

The manure stream is managed as described previously where the liquid phase was routed to a fermenter. The liquid from the sedimentation pit must be diluted about 50 fold to make it suitable for the culture of algae. The flush water provides about 30001 per day so that the liquid leaving the sedimentation pit must be mixed with about 120001 of water before it can be pumped into the algal pond. The pond therefore receives a total of about $15000 \mathrm{l}$ of liquid waste per day. The $12000 \mathrm{l}$ of dilution water have to be provided only once as fresh water. Thereafter, the waste water from the pond is available for reuse as flush water and dilution water after the algae have been harvested.

Loss of water due to evaporation requires make-up water. The rate of evaporation depends on local climatic conditions and on the temperature of the water in the pond. Requirements for fresh make-up water can be substantial when the surface area is large.

The liquid phase of the manure with the effluent from the digester added contains $3.2 \mathrm{~kg} \mathrm{NH}_{3}-\mathrm{N}$ without straw added to the digester and $3.4 \mathrm{~kg}$ with straw added. The expected protein yields are 10 and $10.6 \mathrm{~kg} / \mathrm{day}$, respectively. This system of management has several serious disadvantages (Boersma et al., 1978). These include the instability of the cultures, the large pond requirements, the need for large volumes of water, and problems with bacterial growth. They combine to result in a high cost per unit product and the need for highly developed management skills. The system seems to be less advisable than the use of fermenters.

\section{Harvesting of algae}

Algae may be separated from water by centrifugation or chemical flocculation. Centrifugation on a small scale can be done with yeast separators such as the model YEB 1334A manufactured by the Alpha-DeLaval Co. of Poughkeepsie, New York. This separator has a maximum feed rate of $1000 \mathrm{l} / \mathrm{h}$ and a $0.55 \mathrm{~kW}$ motor. At 
$600 \mathrm{l} / \mathrm{h}$, the centrifuge removes at least $95 \%$ of the biomass, including bacteria. At a dry matter concentration of $1 \mathrm{~g} / 1$ and a flow rate of $600 \mathrm{l} / \mathrm{h}$ the energy consumption would be $0.96 \mathrm{kWh} / \mathrm{kg}$. At $\$ 0.05 / \mathrm{kWh}$ the harvesting cost would be $\$ 0.05 / \mathrm{kg}$ dry matter or $\$ 0.10 / \mathrm{kg}$ protein, assuming a crude protein content of $50 \%(\mathrm{w} / \mathrm{w})$.

One of the most efficient and reliable methods of harvesting microalgae is by chemical flocculation with coagulants such as aluminum sulfate (alum), aluminum chloride, ferric sulfate, lime, and organic polyelectrolytes. This method is expensive and the product is contaminated with the coagulating chemical. Its use as a feed supplement in livestock rations is questionable because of possible toxicity effects and reduced digestibility and palatability.

The least expensive but also the least efficient methods of harvesting algae are sedimentation, autoflocculation, and filtration through microstrainers. The efficiency of microstrainers could be improved significantly by growing filamentous algae instead of single-cell or colonial algae and by increasing the concentration of the filamentous algae. The selection of filamentous algae for the purpose of decreasing the cost of harvesting has disadvantages. Filamentous algae are most often blue-green algae, many of which produce toxins lethal to both man and animal. Strict operational controls as well as product quality controls must therefore be maintained to ensure the safe use of the final product as a feed supplement in livestock rations. Furthermore, the filamentous algae require longer retention times than single-cell algae because of the difference in their rates of growth. The filamentous algae therefore require a correspondlingly larger surface/land area in order to treat the same volume of waste water each day.

\section{Methane and bacteria}

Recovery of useful products from the manure also can be accomplished by emphasizing the growth of bacteria in aerated basins. Manure is routed by gutter flushing to a tank for separation of solids and liquids. The liquid fraction containing only particles smaller than $35 \mu \mathrm{m}$ in length is pumped to an aerated basin. The remaining solids and associated liquids are pumped to an anaerobic digester. The liquid outflow from the digester also is added to the aerated basin after gravity settling to remove solids. Digested solids and associated liquids are stored for use as fertilizer.

\section{Aeration basins}

Aeration basins are operated to maximize the production of bacterial solids from the liquid waste. A much shorter retention time than used in conventional waste treatment systems is required which means that less oxygen and energy is needed. The basin is operated at optimum solids concentration by returning a portion of the bacterial solids to it. The effluent from the basin flows to a solid-liquid separator for harvesting the bacterial biomass. To harvest the solids, a filter which retains particles longer than $5-10 \mu \mathrm{m}$ and gravity settling may be used. The liquid removed from the separator is recycled for use as flush water in the system. The harvested solids are removed as a slurry to be added to the feed supply. This slurry is expected to contain about $4 \%$ solids $(\mathrm{w} / \mathrm{w})$ of which about $60 \%(\mathrm{w} / \mathrm{w})$ are bacterial cells. 
These cells are expected to contain approximately 60 to $75 \%$ protein.

The slurry of bacterial cells is mixed with the dry feed ingredients to eliminate the need for drying. Thus, a liquid feeding system for the pigs is necessary. The total volume of slurry plus feed is expected to equal the daily requirement for water and dry feed combined.

Bacterial cell protein is a relatively high-quality protein for swine feed. Some research has been done on feeding such slurries from oxidation ditches to the animals that produce the waste. No disease problems have been noted to date.

\section{Product yields}

The production of bacterial protein in the aeration basin probably will be limited by the $\mathrm{BOD}_{5}$ supplied to it. Total $\mathrm{BOD}_{5}$ available ranges from 8 to $16 \mathrm{~kg} /$ day. Excess $\mathrm{N}$ enters the aeration basin, but the loss of ammonia $\mathrm{N}$ during the aeration process is expected to bring the system to an equilibrium level. The aeration basin should be operated to produce about $0.6 \mathrm{~kg}$ of suspended solids (micro-organisms) per $\mathrm{kg}$ of $\mathrm{BOD}_{5}$ added. This requires a retention time of approximately $6 \mathrm{~h}$ and a theoretical volume of about 850 liters. The volume should be doubled to allow for foaming and overload. The energy required for aeration would be about 3.1 $\mathrm{MJ} / \mathrm{kg} \mathrm{BOD}$ based on $1.5 \mathrm{~kg} \mathrm{O}_{2} / \mathrm{kg} \mathrm{BOD}_{5}$ added.

The suspended solids are expected to be nearly all bacterial cells with a protein content of about $77 \%$. The protein produced per day would be 3.7 to $7.4 \mathrm{~kg} / \mathrm{day}$ $\left(8.0\right.$ to $16 \mathrm{~kg}$ of $\mathrm{BOD}_{5} /$ day $\times 0.6 \mathrm{~kg}$ of $\left.\mathrm{SS} / \mathrm{kg} \mathrm{BOD}, \times 0.77\right)$. The bacterial protein could replace from 41 to $81 \%$ of the protein provided by the soybean meal supplement.

The digester function and yield would be as described earlier. The gas from the digester can be used to run a generator to supply electricity to the aerators of the basin. Waste heat from the generator could be used to heat the digester.

\section{Conclusions}

Methods for the recovery of energy and protein from swine manure through bioconversion have been discussed. The energy and material balances presented have not been achieved under operating conditions. To realize the indicated levels of energy and protein recovery, much additional research remains to be done. Brief comments about needed research follow.

Economic analyses of alternative farming systems, designed specifically for maximum use of waste products through recovery of energy and nutrient sources for livestock feed, should be performed. The ultimate success of technological development of systems to obtain energy and feed depends on the economic viability of each compared to other alternatives for the utilization of these resources.

Whereas, economic feasibility is important, no less important is manageability by the farmer and reliability of the system of choice in terms of biological stability. The most promising systems, therefore, must be tested under field conditions.

The recovery of useful end products is limited by the availability of nitrogen and organic carbon in the manure. Substantial improvements in the yield of single-cell 
protein and biogas could be realized by the addition of organic carbon to the manure from cellulose containing waste materials, such as crop residues. Emphasis should be on research to solve the technical difficulties involved in converting the cellulose into readily assimilable carbon. Pretreatment of these wastes is necessary to liberate the bound cellulose from hemicellulose and lignin and to maximize the availability of monomeric sugars.

Fermentation methods to be used for converting organic and inorganic materials suspended or dissolved in the liquid phase of the manure by growing yeast or microfungi should be studied in detail. To increase the yield of microbial protein, these studies should include the addition of cellulosic waste materials.

Methods to enhance biogas production by digestion of manure should be studied further. For example, the potential of two-phase anaerobic digestion to improve production rates and yields of methane should be investigated. Phase separation may provide substantial benefits, including reduced digester volume, reduced installation costs, and reduced operating costs. The $\mathrm{C} / \mathrm{N}$ ratio of swine manure is about 10. Yield of biogas with the maximum energy content is higher at the $\mathrm{C} / \mathrm{N}$ ratio of about 30 . Cellulose containing waste products should be studied as digester additives. Pretreatment of these wastes to liberate the bound cellulose from hemicellulose and lignin and to maximize availability of monomeric sugars will be necessary.

Additional assessment of the nutritional value of all products of bioconversion is necessary. Tests should involve assessment of digestibility, protein quality, in the case of proteinaceous materials, through amino acid analysis, biological value, and protein efficiency ratio and replacement value for presently used feedstuffs. Toxicological evaluations should be made in long-term trials with histological examination of the tissues. It would be useful to conduct multi-generation feeding trials.

Growing algae using runoff from the fermenter and/or digester as a substrate remains uncertain. The culture of algae should be studied in further detail. The concept of selecting green algae or blue green algae by adjusting the retention time and recycling a portion of the harvested algae to the growth reactor should be tested under field conditions. Furthermore, processing methods should be developed to improve the digestibility of the algae and the availability of the lysine.

Alternative methods not covered in this report should be considered. A promising method might be the recovery of protein from swine manure using a polyculture of fish and the continuous culturing of bacteria, yeast, or microfungi.

\section{References}

Boersma, L., E. Gasper, J. E. Oldfield \& P. R. Cheeke, 1981. Methods for the recovery of nutrients and energy from swine manure. 1. Biogas. Neth. J. agric. Sci. 29: 3-14.

Boersma, L., E. Gasper, J. R. Miner, J. E. Oldfield, H. K. Phinney \& P. R. Cheeke, 1978. Management of swine manure for the recovery of protein and biogas. Special Report, Agric. Exp. Stn, Oregon State Univ. Corvallis No 507; 264 pp. 
L. BOERSMA, E. GASPER, J. E. OLDFIELD AND P. R. CHEEKE

Forrs, K., K. Passinen \& E. Sjöström, 1974. Utilization of the spent sulfite liquor components in the Pekilo protein process and the influence of the process on the environmental problems of the sulfite mill. In: Wood chemistry, pure and applied (Symposium 31 March-5 April. American Chemical Society.

Humphrey, A. E., 1974. Current developments in fermentation. Chem. Engng 81: 98-112.

Meyrath, J., 1975. Production of feed yeast from liquid wastes. Process Biochem. 10: 20-22.

Sykes, R., 1975. Theoretical heterotrophic yields. J. Water Pollution Control Fedn 47: 591-600. 